\title{
Charting Procedural Due Process and the Fundamental Right to Vote
}

\author{
BEN F.C. WALLACE* \\ TABLE OF CONTENTS
}

I. INTRODUCTION

II. Procedural Due Process In the ConteXt of Voting AND ELECTIONS

A. Lack of Clarity from the Supreme Court ............................ 651

B. Procedural Due Process Under Mathews v. Eldridge ......... 654

C. Lower Court Rulings on Procedural Due Process in Elections

1. Griffin and Roe: Fundamentally Unfair Election Administration 656

2. Courts Applying Mathews in Voting Rights Cases ........ 658

3. Rejecting Procedural Claims 662

III. Anatomy of a Procedural Due Process Claim IN VOTING 666

A. Defining and Weighing the Right(s) at Stake ....................... 666

B. Government Interests 669

C. The Risk of Erroneous Deprivation and the Benefits of Additional Procedures

D. Extent of Notice 671

E. Timing of Opportunity to Be Heard 672

IV. Ghosts in the Machine: Searching for Procedural Due Process Violations IN THE Electoral Process 673

A. Provisional and Absentee Ballots 673

1. Provisional and Absentee Ballots 673

2. Voter Challenges and the Right to Vote by Regular Ballot..... 677

B. Poll Worker Error and Wrong Precinct Voters 678

C. Felon Disenfranchisement 679

V. CONCLUSION: THE BENEFITS FOR Voting RightS OF ExPloring Procedural Due Process Claims 681

\section{INTRODUCTION}

Voting can be complicated. The case of Apryl Babarcik is illustrative. In November 2012, Apryl resided at 231 3rd Drive SE, in the small town of New

*J.D. Candidate 2016, The Ohio State University Moritz College of Law. 
Philadelphia, Ohio. ${ }^{1}$ On November 6th, the date of the election pitting President Obama against challenger Mitt Romney, Apryl attempted to vote at the correct polling location for her address. However, when she arrived at the polls, the local election officials insisted that she was at the incorrect voting location. The poll workers directed her to the polling location for a similar, yet incorrect address: 231 3rd Drive NE. Apryl followed the poll worker's instructions, but because she was not in the poll book at that polling location, she was forced to vote a provisional ballot, as required under the Help America Vote Act (HAVA). ${ }^{2}$ Unbeknownst to Apryl, her ballot would not be counted. Despite the fact that she was an eligible voter in the state of Ohio and was registered at her current address, Ohio law does not permit ballots to be counted if they are cast in the wrong polling location. ${ }^{3}$

In every American election, thousands of voters like Apryl have their ballots discarded for this very same reason. ${ }^{4}$ Others have their ballots discarded because information is missing from that ballot. ${ }^{5}$ Many other Americans who have been convicted of a felony but who are eligible to vote are unable to register because they do not have proper documentation of their eligibility. ${ }^{6}$

These voters, as well as Apryl Babarcik, were deprived of their right to vote through a process that failed to protect that right. They were denied a fundamental right without being properly informed and without an opportunity to explain: they were, arguably, denied the right to vote without being provided with Due Process as guaranteed by the Fifth and Fourteenth Amendments.

The contours of this right are, in the context of voting in elections, not well defined. While the Supreme Court has outlined the basic standard of Procedural Due Process as requiring notice and an opportunity to be heard, ${ }^{7}$ it has never squarely (or indeed, obliquely) addressed how these requirements apply to voting. ${ }^{8}$ While the Court has consistently recognized that voting in federal elections and having that vote counted is a fundamental right-perhaps the most fundamental right ${ }^{9}$ - and worthy of Due Process protection, the

${ }^{1}$ Edward B. Foley, Ballot Battles: The History of Disputed Elections (2016).

${ }^{2}$ Help America Vote Act of 2002, 52 U.S.C. $§ 21082$ (Supp. II 2014).

${ }^{3}$ OHIO REV. CODE ANN. § 3505.181 (West 2007).

${ }^{4}$ Joshua Field et al., Uncounted Votes: The Racially Discriminatory Effects of Provisional Ballots, CTR. FOR AM. PROGRESS (Oct. 29 2014), https://www.american progress.org/issues/race/report/2014/10/29/99886/uncounted-votes/ [https://perma.cc/ZEM4MU3W].

5 Id.

${ }^{6}$ See Jessie Allen, Documentary Disenfranchisement, 86 TuL. L. REV. 389, 389 (2011).

${ }^{7}$ Mathews v. Eldridge, 424 U.S. 319, 349 (1976).

${ }^{8}$ The Court's seminal election administration cases have been based on general Fourteenth Amendment grounds. See infra Part II.A.

${ }^{9}$ See infra Part III.A. 
process for determining when and how a voter may cast a ballot and for whether or not that ballot will be counted, are largely left with the individual states, which have plenary power over the conduct of elections. ${ }^{10}$

Regardless of what process states are constitutionally required to afford to voters, the actual process of registering, voting, administering elections, and counting ballots has become quite complex. ${ }^{11}$ Some of this complexity stems from a growing electorate; local elections officials must offer their services to a growing number of voters under the constraints of limited public resources. ${ }^{12}$ The continuous technological evolution of society adds complexity: many voters now fill out their ballots electronically or register to vote on the Internet. ${ }^{13}$ Some complexity is self-inflicted, via statute. The National Voter Registration Act (NVRA) imposes requirements on states to update voters' registration and limits their ability to remove voters from the rolls. ${ }^{14}$ The Help America Vote Act (HAVA) requires states to offer provisional ballots to voters whose eligibility is in question. ${ }^{15}$ Most states require voters to present proof of identification, with some requiring state-issued photo ID. ${ }^{16}$ While some of these statutes are assets for voting rights advocates and litigators, they nevertheless add procedural wrinkles to voting and election administration that may complicate vote counting, election administration, and the essential elements of casting a ballot, with the accompanying risk that these procedures may disenfranchise eligible voters.

While voting has become more complex, voting rights advocates recently lost what had been an indispensable tool in efforts to preserve the electoral franchise. The Supreme Court's 2012 decision in Shelby County v. Holder invalidated the formula Congress used to determine which jurisdictions were required to "preclear" changes in their voting laws with the Department of Justice. ${ }^{17}$ The decision, for the time being, ended the preclearance regime that, since 1965, had ensured that many states did not pass racially discriminatory voting laws. Following Shelby County, many states of the former Confederacy, which had been covered by the preclearance requirement, passed laws requiring photo identification in order to vote. ${ }^{18}$

This Note will present the first thorough exploration of a largely neglected

${ }^{10}$ See U.S. CONST. art. I, $\S 4$.

${ }^{11} \mathrm{See}$ THE AMERICAN VOTING EXPERIENCE: REPORT AND RECOMMENDATIONS OF THE Presidential COMMISSION ON EleCtion AdMINISTRATION 9 (Jan. 2014) [hereinafter PREsidential CoMmission], https://www.supportthevoter.gov/files/2014/01/Amer-VotingExper-final-draft-01-09-14-508.pdf [https://perma.cc/QXK3-BBZK].

12 Id. at 10.

${ }^{13} \mathrm{Id}$. at $11-13$.

${ }^{14}$ National Voter Registration Act, 52 U.S.C. \$ 20501 (2013).

${ }^{15}$ Help America Vote Act of 2002, 52 U.S.C. $\$ 21082$ (Supp. II 2014).

16 Voter Identification Requirements, NAT'L CONF. ST. LEGISLATURES (Dec. 14, 2015), http://www.ncsl.org/research/elections-and-campaigns/voter-id.aspx [https://perma.cc/ 3V34-NER7] [hereinafter NCSL].

${ }^{17}$ Shelby Cty. v. Holder, 133 S. Ct. 2612, 2631 (2013).

${ }^{18}$ NCSL, supra note 16. 
tool for protecting and litigating voting rights: Procedural Due Process under the Fifth and Fourteenth Amendments. This Note will argue that, in the wake of Shelby County, Procedural Due Process claims will advance the larger mission of voting rights advocates in three ways: (1) it offers an alternative basis for a claim against voting laws which are restrictive, but not necessarily discriminatory; (2) the prospect of Procedural Due Process claims may induce state and local election officials to ensure uniformity in their procedures; and (3) Procedural Due Process claims will develop a body of law that has been stunted, with the prospect that courts will begin to recognize the validity of these claims.

This Note contributes to an ever-growing body of academic work that seeks to find alternative remedies for voting rights plaintiffs in the wake of Shelby County. Some writers have searched for ways to expand other provisions of the Voting Rights Act. ${ }^{19}$ Others have speculated on ways in which Congress might amend the Section 4 preclearance formulas to breathe new life into Section 5.20 These are commendable goals, and many of these academic positions are worth pursuing. This Note does not seek to supplant these efforts to reinvigorate the Voting Rights Act. On the contrary, while voting rights advocates should resuscitate the preclearance regime, there is a unique window of opportunity for litigators to pursue Procedural Due Process claims in the arena of voting rights. If this body of law is developed, voting rights advocates will have an expanded arsenal with which to challenge restrictive voting laws, voting technology, and procedures continue to become more complex in the 21 st century. ${ }^{21}$

Part II of this Note discusses the Supreme Court's approach to election administration and Procedural Due Process, as well as the leading cases in which lower courts have heard claims of Procedural Due Process violations in the context of elections. Part III will outline some of the basic elements of a claim of Procedural Due Process violations as it pertains to voting rights and election administration. Part IV will suggest some aspects of election administration that present targets of opportunity for voting rights litigators to

${ }^{19}$ See, e.g., Christopher S. Elmendorf \& Douglas M. Spencer, The Geography of Racial Stereotyping: Evidence and Implications for VRA Preclearance After Shelby County, 102 CALIF. L. REV. 1123, 1123 (2014) (proposing a new Section 4 coverage formula); Brian F. Jordan, Note, Finding Life in Hurricane Shelby: Reviving the Voting Rights Act by Reforming Section 3 Preclearance, 75 OнIо ST. L.J. 969, 972 (2015) (discussing the rarely used provision of Section 3 of the Voting Rights Act that allows courts to impose preclearance on a jurisdiction after finding a Section 2 violation); Paul M. Wiley, Note, Shelby and Section 3: Pulling the Voting Rights Act's Pocket Trigger to Protect Voting Rights After Shelby County v. Holder, 71 WASH. \& LEE L. REV. 2115, 2119 (2014).

${ }^{20}$ See, e.g., Gilda R. Daniels, Unfinished Business: Protecting Voting Rights in the Twenty-First Century, 81 GEO. WASH. L. REV. 1928, 1934 (2013); Hayley Trahan-Liptak, Note, Prohibiting Barriers to the Booth: The Case for Limited Nationwide Preclearance Under a Modified Voting Rights Act, 34 B.C. J.L. \& Soc. JusT. 151, 151 (2014).

${ }^{21}$ See infra Part IV. 
bring Procedural Due Process claims. This Note will conclude by arguing that voting rights advocates and litigators should focus more attention on Procedural Due Process and discussing some potential benefits of bringing these claims.

\section{Procedural Due Process in the Context of Voting AND ELECTIONS}

Although the Supreme Court has never directly decided on what procedural protections are afforded to voters by the Due Process Clause, that has not prevented litigants from bringing such claims and has not constrained lower federal courts from finding that voting rights are protected by the Due Process Clause. This Part will discuss the indeterminate scope of the Supreme Court's election administration jurisprudence. It will then provide an overview of the Supreme Court's test for determining the validity of procedures that deprive individuals of Constitutional rights under Mathew v. Eldridge. This Part will then discuss the principal cases in which lower federal courts have heard claims of violation of Procedural Due Process in the context of voting and election administration.

\section{A. Lack of Clarity from the Supreme Court}

The Supreme Court has struggled to formulate a consistent standard for deciding claims of deprivation of constitutional rights arising from election administration issues. ${ }^{22}$ Although the Court's approach to such cases has become more refined since the 1970s, there are still lingering questions about how these cases are to be dealt with.

The foundational case for the Supreme Court's contemporary jurisprudence on the intersection of individual rights and election administration is the 1974 decision in Storer v. Brown, a challenge to California's ballot access laws by independent candidates for federal office. ${ }^{23}$ The majority opinion in that case recognized that, while the right to vote was important and fundamental, regulation of elections was essential to the ultimate purpose and legitimacy of elections. ${ }^{24}$ The Court also recognized that there could be no bright line rules or precise tests for determining when election administration rules and procedures infringe upon constitutional rights. ${ }^{25}$

${ }^{2}$ See Edward B. Foley, Voting Rules and Constitutional Law, 81 GEO. WASH. L. REV. 1836, 1847-48 (2013).

23 Storer v. Brown, 415 U.S. 724, 724 (1974).

${ }^{24} \mathrm{Id}$. at 730 ("[T] fair and honest and if some sort of order, rather than chaos, is to accompany the democratic processes.").

${ }^{25} I d$. (holding that there can be "no litmus-paper test" for determining whether particular election administration practices infringe on the rights of voters, and called on 
While the Storer decision was based on the Equal Protection Clause, in Anderson v. Celebrezze the Court expanded its reasoning to embrace other Constitutional protections of individual rights and held that the same mode of analysis applied not just to ballot access regulations, but also to all election administration provisions. ${ }^{26}$ Anderson was a challenge to Ohio's early petition filing deadline imposed on third-party candidates. ${ }^{27}$ However, the decision in Anderson applied not only to access to the ballot by candidates, but also to "the registration and qualifications of voters... [and] the voting process itself." 28 The language of Anderson also expanded the scope of the balancing test to apply not only to Equal Protection claims, but also to any "rights protected by the First and Fourteenth Amendments that the plaintiff seeks to vindicate." 29 The precise basis of the holding in Anderson - that the early filing deadline impermissibly burdened the rights of voters-was deliberately imprecise. In a footnote, the Court noted that its decision was based "directly on the First and Fourteenth Amendments." ${ }^{30}$ The somewhat squishy basis for the balancing test in election administration cases was later affirmed in Norman v. Reed. ${ }^{31}$

The Court's decision in Burdick v. Takushi ${ }^{32}$ completed the evolution from a loose, flexible standard, to a more established balancing test, weighing first the magnitude of the deprivation of the right to vote and then balancing that with the State's asserted interest. ${ }^{33}$ Under Burdick, severe burdens on

courts to make the necessary "hard judgments" in such cases based on "the facts and circumstances behind the law, the interests which the State claims to be protecting, and the interests of those who are disadvantaged" (last quoting Williams v. Rhodes, 393 U.S. 23, $30(1968))$ ).

${ }^{26}$ Anderson v. Celebrezze, 460 U.S. 780, 781 (1983).

27 Id. at $782-83$.

${ }^{28}$ Id. at 788 . And the Court had previously held that the issues involved in ballot access cases are generally the same as more direct voting rights cases. Bullock v. Carter, 405 U.S. 134, 143 (1972) ("[T] he rights of voters and the rights of candidates do not lend themselves to neat separation ....").

${ }^{29}$ Anderson, 460 U.S. at 789.

${ }^{30} \mathrm{Id}$. at 786 n.7.

${ }^{31}$ Norman v. Reed, 502 U.S. 279, 288 n.8 (1992). The Court in Norman appropriated the relevant language from Anderson directly, without elaboration or explanation. Id. Any lingering doubt on the doctrinal scope of this line of cases was removed by Crawford $v$. Marion County Election Board, in which the Supreme Court applied Anderson and Burdick to a challenge that dealt directly with the rights of voters. Crawford v. Marion Cty. Election Bd., 553 U.S. 181, 190-91 (2008) (plurality opinion).

Norman also firmly established that there are no mootness issues when an election administration dispute is not adjudicated until after the election can be passed and affirmative relief cannot be afforded to the plaintiff. The Court in Norman held that such cases are "capable of repetition, yet evading review." Norman, 502 U.S. at 287-88 (quoting Moore v. Ogilvie, 394 U.S. 814, 816 (1969)).

32 Burdick v. Takushi, 504 U.S. 428 (1992).

${ }^{33}$ Christopher S. Elmendorf, Structuring Judicial Review of Electoral Mechanics: Explanations and Opportunities, 156 U. PA. L. REV. 313, 335-48 (2007). 
constitutional rights relating to elections receive strict scrutiny, while reasonable and nondiscriminatory burdens are evaluated using a rational basis test. $^{34}$

However, the manner in which these burdens should be measured resulted in a fractured Court in Crawford v. Marion County Election Board. ${ }^{35}$ The case involved a facial challenge to Indiana's voter photo identification law. The Court upheld the law, but could not agree on the proper application of Burdick. Three Justices noted that while the law applied equally to all voters, the burden of having to present state-issued photo identification at the polls was not the same across all classes of citizens. ${ }^{36}$ Three justices rejected this approach as inconsistent with precedent, including Burdick, and argued that the better and more consistent approach was to consider the effect of burdens on the electorate as a whole, and not to consider, as a general rule, burdens on individual voters or classes of voters. ${ }^{37}$ The splintered decision in Crawford therefore left not only the long-term status of voter photo ID statutes in flux, but leaves questions about the proper application of Burdick and the cases which preceded it.

Before concluding this discussion of Supreme Court election administration cases, one final Supreme Court decision begs for analysis: Bush v. Gore. ${ }^{38}$ That famous (or infamous) decision, offers several insights for those considering the application of Procedural Due Process to voting rights and election administration. The decision is the closest the Court has ever come to articulating that Procedural Due Process protects voting rights, which was among the arguments advanced by the petitioners. ${ }^{39}$ Moreover, several scholars have argued that the reasoning of the Court's majority was better suited to a Procedural Due Process, rather than an Equal Protection, holding. ${ }^{40}$ The Court did not rely at all on any of the Storer-Anderson-Burdick line of

${ }^{34}$ Burdick, 504 U.S. at 434.

${ }^{35}$ Crawford, 553 U.S. at 181 (arguing that the law violated the Equal Protection Clause).

${ }^{36} I d$. at $197-99$ (plurality opinion).

${ }^{37} \mathrm{Id}$. at 206-08 (Scalia, J., concurring in the judgment) ("This is an area where the dos and don'ts need to be known in advance of the election, and voter-by-voter examination of the burden of voting regulations would prove especially disruptive.").

${ }^{38}$ Bush v. Gore, 531 U.S. 98, 98 (2000) (per curiam). The case arose from the disputed presidential election in Florida. The Court ruled that the Florida Supreme Court's order that election officials complete a recount of all ballots in the state without uniform rules for determining the intent of the voters violated the Equal Protection Clause. Id.

${ }^{39}$ Brief for Petitioners, Bush, 531 U.S. 98 (No. 00-949), 2000 WL 1810102, at*4549.

${ }^{40}$ Richard A. Posner, Breaking the Deadlock: The 2000 Election, the CONSTITUTION, AND THE COURTs 130-32 (2001); Richard A. Epstein, "In Such Manner as the Legislature Thereof May Direct": The Outcome in Bush v. Gore Defended, in THE Vote: Bush, Gore, And the Supreme Court 13, 18 (Cass R. Sunstein \& Richard A. Epstein eds., 2001); Peter M. Shane, Disappearing Democracy: How Bush v. Gore Undermined the Federal Right to Vote for Presidential Electors, 29 Fla. ST. U. L. REV. 535, 552-53 (2001). 
cases, perhaps indicating that the Court found them inapplicable in the context of a disputed election, or perhaps simply a side effect of the majority's wish to limit the impact of its decision "to the present circumstances." 41

This survey of contemporary Supreme Court jurisprudence on election administration raises several questions which are germane for this discussion, but one question is paramount: do these cases, which concern, "rights protected by the ... Fourteenth Amendment,"42 subsume the right to Procedural Due Process within a generalized framework for analyzing challenges to state election administration? The appropriate test, as articulated in Burdick, bears some superficial similarity to the Mathews test, considering the particular state interest in the regulatory scheme and the severity of the burden to voters. The Court certainly treats these as special cases, where judicial restraint and a degree of deference to state administrative prerogatives is necessary, ${ }^{43}$ even in light of the profound importance of the individual rights that are at stake; perhaps this approach means that the Court may not view Mathews as an appropriate tool for such cases. ${ }^{44}$ However, until and unless the Supreme Court says so explicitly, courts should continue to evaluate claims of violations of Procedural Due Process arising from elections under the Mathews balancing test, which will be discussed in the next Section.

\section{B. Procedural Due Process Under Mathews v. Eldridge}

The seminal test for whether a government action violates Procedural Due Process rights is found in Mathews $v$. Eldridge $e^{45}$ and its progeny. Courts must first answer the threshold question of whether a protected life, liberty, or property interest exists. ${ }^{46} \mathrm{~A}$ court must then determine what amount of process the government must afford individuals before they are deprived of that interest. ${ }^{47}$

The Supreme Court's conception of liberty interests under the Due Process Clause is expansive. Traditionally, guarantees of liberty from government restraint applied to only physical restraint and punishment. ${ }^{48}$ The Supreme

${ }^{41}$ Bush, 531 U.S. at 109; see Foley, supra note 22, at 1851-54.

42 Anderson v. Celebrezze, 460 U.S. 780, 789 (1983).

${ }^{43}$ Elmendorf, supra note 33, at 327-28. As Elmendorf points out, too much judicial regulation of election administration would itself be a burden on the rights of voters by preventing experimentations that may benefit voters.

${ }^{44}$ Although the Court has applied Mathews in a wide variety of cases, it has also cautioned that it should not be viewed as applicable in all Procedural Due Process cases. Dusenbery v. United States, 534 U.S. 161, 167-68 (2002) ("[W]e have never viewed Mathews as announcing an all-embracing test for deciding due process claims.").

${ }^{45}$ Mathews v. Eldridge, 424 U.S. 319, 323 (1976). Mathews involved a challenge to the procedures for terminating Social Security disability benefits.

${ }^{46} I d$. at 332; Morrissey v. Brewer, 408 U.S. 471, 481 (1972).

${ }^{47}$ Morrissey, 408 U.S. at 481.

${ }^{48}$ E. Thomas Sullivan \& Toni M. Massaro, The Arc of Due Process IN AMERICAN CONSTITUTIONAL LAW 68 (2013). 
Court has expanded this basket of rights to include the rights that are "essential to the orderly pursuit of happiness by free men." 49 State laws that use mandatory language limiting the discretion that government officials may use when depriving individuals of constitutional rights may also create liberty interests. ${ }^{50}$

Under Mathews, if an individual has been deprived of a constitutional right, courts use a three-factor balancing test to determine whether or not the procedures used to deprive that right comply with Due Process, weighing: (1) the private or individual interest that is implicated; (2) the risk of "erroneous deprivation" through the procedures currently in place and the probable value of any additional procedures; and (3) the government interests at stake, including any "fiscal and administrative burdens" that additional procedures would create. ${ }^{51}$

The two touchstones of Procedural Due Process are notice and the opportunity to be heard. ${ }^{52}$ Notice may be any communication by government officials that is reasonably calculated to inform the individual that state action is being taken against a constitutionally protected interest. ${ }^{53}$ Notice must be a component of any constitutionally required process, but, based on the Mathews test, notice may be given either before or after any constitutional deprivation, based on the circumstances. ${ }^{54}$ Notice may also take multiple forms, from general communications to the population in a newspaper to verified, personal communication with an individual. The opportunity to be heard can also take many forms. At a minimum, the opportunity to be heard includes the right to address the witnesses or evidence being used to justify the adverse action and the chance to present counter evidence either orally or in writing. ${ }^{55}$ Whatever its form, the timing of a hearing is crucial, but also flexible under Mathews.

\section{Lower Court Rulings on Procedural Due Process in Elections}

While the Supreme Court has never ruled on how Procedural Due Process applies in the context of voting rights and election administration, lower courts have occasionally ruled on such claims. This Section will discuss the contours and scope of those holdings.

${ }^{49}$ Meyer v. Nebraska, 262 U.S. 390, 399 (1923).

${ }^{50}$ SULLIVAN \& MASSARO, supra note 48 , at 68 n.220.

51 Mathews, 424 U.S. at 335.

52 Rhonda Wasserman, Procedural Due Process: A Reference Guide to the UNITED STATES CONSTITUTION 63 (2004).

${ }_{53}$ Mullane v. Cent. Hanover Bank \& Tr. Co., 339 U.S. 306, 314 (1950).

${ }^{54}$ See Mathews, 424 U.S. at 334; see also Morrissey v. Brewer, 408 U.S. 471, 481 (1972)

55 See Mathews, 424 U.S. at 349. 


\section{Griffin and Roe: Fundamentally Unfair Election Administration}

One of the leading cases on Procedural Due Process and election administration is Griffin v. Burns. ${ }^{56}$ The case emerged from a disputed city council primary election in Providence, Rhode Island, in which a losing candidate sought to have absentee ballots disqualified in state court, claiming that state law did not allow for such ballots to be cast in primary elections..$^{57}$ However, the practice and legal opinion of the Rhode Island Secretary of State was that absentee ballots were available to voters in primary elections, and had therefore publicly announced that absentee ballots could be obtained through application to the state Board of Canvassers. ${ }^{58}$ However the Rhode Island Supreme Court ruled that there was no right to vote by absentee ballot under state law and ordered that those ballots be discounted, upsetting the result of the election..$^{59}$ The originally declared winner, along with several voters who had cast absentee ballots, filed suit in federal court, claiming that they had been denied the right to vote. ${ }^{60}$

The First Circuit Court of Appeals issued an expansive ruling on the suitability of the case for federal courts and the nature of the plaintiffs' claims. ${ }^{61}$ The crux of the issue, as the Court saw it, was that the absentee ballots were presumed to be valid by everyone involved-from the Secretary of State, to the election administrators, and of course, the voters-at the time the ballots were cast. The voters "were doing no more than following the instructions of the officials charged with running the election," and when those ballots are not counted despite the fact that the legal understanding at the time of the election indicated that they were valid, "the election itself becomes a flawed process." 62 The touchstone for whether federal courts should hear claims of violations of Due Process in the context of elections, according to the Court, was fairness: "If the election process itself reaches the point of patent and fundamental unfairness, a violation of the due process clause may be indicated and relief under $\S 1983$ therefore in order." 63 According to the Griffin court, the unfairness need not be deliberate, partisan, or malicious in

${ }^{56}$ Griffin v. Burns, 570 F.2d 1065 (1st Cir. 1978).

${ }^{57} \mathrm{Id}$. at 1067.

${ }^{58} \mathrm{Id}$.

${ }^{59} \mathrm{Id}$. at 1068.

${ }^{60}$ Id. at 1074 . The plaintiffs' claims were brought under 42 U.S.C. $\S 1983$. Id. at 1070 .

${ }^{61}$ See id. at $1069-70$ (The district court had ordered a new primary election and delayed the subsequent general election).

62 Griffin, 570 F.2d at 1075-76.

${ }^{63} \mathrm{Id}$. at 1077 . The Court did not explain whether this reasoning applied to the substantive component of the Due Process Clause or the specifically procedural guarantees of Due Process. However, the Court's explanation of its reasoning indicates that it applies to Procedural Due Process claims. See infra note 65. 
any way. ${ }^{64}$ The court did not apply the Mathews test but indicated that when evaluating when Due Process had been violated, "the availability of a fully adequate state corrective procedure is germane." 65 The court cautioned that this was an exceptional case, that the bar should be set high for federal courts to hear election administration claims, and that federal courts should avoid intervening in "garden variety election irregularities."66 While this element of the Griffin decision-admonishing courts to be cautious in hearing constitutional claims stemming from ordinary election disputes, or commonplace administrative error - has been perhaps the element most widely cited by other courts, ${ }^{67}$ the language and reasoning of the decision may provide support for litigants to bring claims relating to the discounting of both absentee and provisional ballot deficiencies. ${ }^{68}$

Another federal appeals court has ruled that procedural irregularities may also cut the other way: to affirm the disenfranchisement of voters who believed they were in compliance with election administration laws. In Roe $v$. Alabama, the Eleventh Circuit ruled that counting improperly certified absentee ballots would "implicat[e] fundamental fairness issues" and violated the Due Process Clause. ${ }^{69}$ The case arose during a disputed election in Alabama, where state law required that absentee ballots be accompanied by the attestation of two witnesses to the identity of the voter and an affirmation by the voter herself. ${ }^{70} \mathrm{~A}$ state court had ordered that several hundred ballots

${ }^{64}$ Griffin, 570 F.2d at 1077 (stating that federal courts may grant relief from unfair election practices "even if derived from apparently neutral action").

65 Id. This statement also indicates that the court was articulating a Procedural Due Process test. Under the substantive component of the Due Process clause, no amount of procedure may cure a deprivation of a constitutionally guaranteed right, in this case the right to vote and to have that vote counted. The court discussed the salience of "adequate state corrective procedures" and "the state's administrative and judicial corrective process" to any determination as to whether there has been a constitutional violation, but does not specifically articulate how the availability, or lack thereof, factor into the analysis. $I d$. at 1077-78.

${ }^{66} \mathrm{Id}$. at 1076.

${ }^{67}$ See Bennett v. Yoshina, 140 F.3d 1218, 1226 (9th Cir. 1998); Dickie v. Rabbit, 956 F. Supp. 67, 70 (D. Mass. 1997).

68 See infra Part III.B. At least one court has read Griffin as preventing election administration practices that lead to voters miscasting their ballots. See, e.g., Ne. Ohio Coal. for the Homeless v. Husted, 696 F.3d 580, 597 (6th Cir. 2012) (explaining that "state actions that induce voters" violate Due Process under Griffin).

It also bears noting that the reluctance of the Griffin court to intervene in cases that do not rise to the level of "fundamental unfairness," may be influenced by the fact that these were disputed elections, not claims of infringement on the right to vote standing alone. Although disputes about voting rights are never far removed from consideration of electoral politics, the admonishments of Griffin may bear less force when plaintiffs bring claims that are not tied to the outcome in a disputed electoral contest.

${ }^{69}$ Roe v. Alabama, 43 F.3d 574, 580-81 (11th Cir. 1995) (per curiam).

${ }^{70} \mathrm{Id}$. at 577. 
that lacked these statutory requirements nevertheless be counted. ${ }^{71}$ Several voters and candidates filed suit under 42 U.S.C. $\$ 1983$ in federal court contesting the counting of these ballots, and the district court ruled in their favor. ${ }^{72}$ The defendants, local election officials, appealed to the Eleventh Circuit, claiming, among other things, that the plaintiffs had not properly stated any constitutional deprivation. ${ }^{73}$ The Eleventh Circuit affirmed the district court decision, relying chiefly on the Griffin precedent as adopted by that circuit to hold that fundamental unfairness gives rise to a claim under $\S 1983$ for violation of due process. ${ }^{74}$

Although Griffin and Roe may offer limited utility to voting rights litigators, as opposed to disputed election litigators, ${ }^{75}$ the principles underlying these decisions support claims of Procedural Due Process in elections. That principle is that where there are rules, those rules must be followed.

\section{Courts Applying Mathews in Voting Rights Cases}

Several federal courts have used the test from Mathews v. Eldridge to evaluate election procedures that result in a denial of the right to vote. This subsection will discuss those cases and extract broader principles that may be instructive for litigators considering bringing such claims.

In Williams v. Taylor, the Fifth Circuit applied Mathews to evaluate the Procedural Due Process claim of a felon who was denied the right to vote. ${ }^{76}$ The plaintiff in Williams was a convicted felon, who was removed from the voting rolls through a process that deviated from the state mandated procedures established under Mississippi Law. ${ }^{77}$ The plaintiff challenged the apparent lack of procedure attending his removal from the voter rolls,

${ }^{71} \mathrm{Id}$. at 578 .

$72 \mathrm{Id}$. at 579 . The plaintiffs claimed that by following the district court's order to count the illegal ballots the local Alabama election officials had violated their constitutional "rights to vote and ... have their votes properly and honestly counted" and the result was a "fundamental unfairness." Id. at 580 (alteration in original) (last quoting Curry v. Baker, 802 F.2d 1302, 1315 (1986)).

${ }^{73} \mathrm{Id}$. at 580 .

${ }^{74} \mathrm{Id}$. ("If, however, 'the election process itself reaches the point of patent and fundamental unfairness, a violation of the due process clause may be indicated and relief under $\S 1983$ therefore in order."' (quoting Curry, 802 F.2d at 1315)).

75 These cases could potentially be distinguished from many voting rights claims, because a crucial element of the fact pattern in both Griffin and Roe was the intervention of state courts which had the effect in both cases of upsetting settled state law and election procedures, as discussed above. See supra Part II.C.1.

76 Williams v. Taylor, 677 F.2d 510, 510 (5th Cir. 1982).

${ }^{77} I d$. at $513-14$. The facts from the trial in the case did not clearly establish how the local election officials learned of the plaintiff's felony conviction, but they did establish that procedure under state law requires county clerks to compare the list of the citizens convicted in county courts to county voter rolls and remove those convicted of felonies from the rolls. Id. 
including lack of prior notice. ${ }^{78}$ The plaintiff claimed that if he had received notice and an opportunity to be heard, he would have raised the state's statute of limitations as a defense. ${ }^{79}$

The court applied Mathews and held that the state's procedures had been sufficient in that case. The court distinguished between the right to vote of felons and non-felons. ${ }^{80}$ Felons did not have an unqualified right to vote under state law, and since the rights at stake were fundamentally different than the right to vote in general, the court did not find that, under the second prong of the Mathews analysis, additional procedures were likely to yield more accurate results. The court also held that requiring the state to provide a hearing prior to removing voters from the rolls would cost the state "substantial time and money" and was not necessary given the unlikelihood that such procedures would yield better results. ${ }^{81}$

While the decision in Williams v. Taylor runs counter to goals of voting rights advocates, the decision shows that Mathews is a viable tool for attacking the procedures for removing felons (or those believed to be felons) from voting rolls. The fatal flaw in this litigation seems to have been the fact that the plaintiff was, in fact, a felon, and not a voter erroneously labeled as such and denied the right to vote. The decision points to the factual showing that is probably necessary for plaintiffs to succeed: that non-felons are being disenfranchised because of procedural deficiencies. ${ }^{82}$

By contrast, in Doe v. Rowe, ${ }^{83}$ the procedure at issue was used to make a far less determinative designation. Doe challenged state procedures for placing an adult in guardianship as a deprivation of the right to vote without notice and opportunity to be heard on that specific deprivation. In 1965, the Constitution of Maine was amended to provide that persons who are under guardianship for

78 Again, there was a factual dispute as to whether the plaintiff had received actual notice that his registration had been cancelled. The election officials claimed to have notified the plaintiff with a standard form letter that the plaintiff claimed he had never received. $I d$. at 514.

${ }^{79}$ As the 5th Circuit panel noted, this would not have been a valid claim under Mississippi law, since removal from voter rolls was not an action that fell under that statute. Id. at 515 .

${ }^{80}$ The court reasoned that the plaintiff was facially ineligible to vote. The court did not engage in a detailed analysis of the state procedures under Mathews, but reasoned that those procedures were per se constitutional because the Supreme Court had upheld "procedures fundamentally identical" to those in Mississippi. Id. at 514 (citing Richardson v. Ramirez, 418 U.S. 24, 28-31 (1974) (upholding the constitutional validity of felon disenfranchisement in general)). The Williams court relied on Richardson v. Ramirez in spite of the fact that the court in Ramirez had not scrutinized the procedural requirements pertaining to felon disenfranchisement. $I d$. at 514-15.

${ }^{81} \mathrm{Id}$. at 515 .

82 Williams, 677 F.2d at 515 ("Appellant does not contend that this procedure prevents nonfelons from voting or that it reaches felons who have received a pardon from the governor. There is no evidence in the record to justify such an assumption, even remotely.").

${ }^{83}$ Doe v. Rowe, 156 F. Supp. 2d 35, 38-39 (D. Me. 2001). 
mental illness were ineligible to vote. ${ }^{84}$ Three plaintiffs who were under state guardianship and wished to vote, as well as an advocacy organization, brought suit against the state.

Both parties agreed that Mathews provided the appropriate standard for analyzing the plaintiffs' Procedural Due Process claim, and the court applied that test. ${ }^{85}$ At the outset, the court classified voting as a liberty interest, ${ }^{86}$ and determined that the right at stake-the right to vote-was a "fundamental liberty." 87 The court found that the risk of erroneous deprivation was high, because individuals undergoing guardianship proceedings were given no notice that the procedure would result in a deprivation of their right to vote, which simultaneously led to a total lack of opportunity to be heard on the issue of their qualification to vote. ${ }^{88}$ The court also determined that there was no state interest in not providing these additional procedures, since they might actually reduce the burden on state probate courts. ${ }^{89}$ Therefore, the court in Doe concluded that Maine's procedures for placing citizens under guardianship were constitutionally deficient with respect to the fundamental right to vote of those citizens. ${ }^{90}$

The final case in which a federal court has applied the Mathews Procedural Due Process test in the context of voting rights is perhaps the most useful for voting rights advocates and litigators. In Raetzel v. Parks/Bellemont Absentee Election Board, ${ }^{91}$ a federal district court in Arizona applied Mathews to procedures used to process and determine the validity of absentee ballots. The court first determined, as did the Rowe court, that voting is a fundamental liberty interest that may not be deprived without constitutionally sufficient due process, as determined under the Mathews analysis. ${ }^{92}$ However, the court next noted absentee voting was not itself a fundamental right, but a "privilege and a

${ }^{84} \mathrm{Id}$.

${ }^{85} \mathrm{Id}$. at 47 . The court adapted the overall purpose of the Mathews test in this context as "striking a balance that will minimize the risk of the State erroneously disenfranchising persons who have the capacity to vote." Id. at 48.

${ }^{86}$ As opposed to an interest in "life" or "property." See U.S. ConST. amend. XIV.

${ }^{87}$ Doe, 156 F. Supp. 2d at 48. The court cited as authority Harper v. Virginia Board of Elections, 383 U.S. 663 (1966), and Griffin v. Burns, 570 F.2d 1065 (1st Cir. 1978), as precedent that voting was a fundamental liberty interest and that Procedural Due Process was the appropriate analysis, respectively. The court also cited as precedent for the proposition that deprivation of voting rights are subject to the Mathews analysis, Raetzel v. Parks/Bellemont Absentee Election Board, 762 F. Supp. 1354 (D. Ariz. 1990), which is the next case discussed in this Section.

${ }^{88}$ Doe, 156 F. Supp. 2d at 48-49.

${ }^{89} \mathrm{Id}$. Unfortunately, this reasoning may have little value for voting rights litigators in other contexts, since the state administrative burden in Doe fell upon state probate courts, not election officials.

${ }^{90} \mathrm{Id}$. at $50-51$.

91 Raetzel, 762 F. Supp. at 1358.

${ }^{92} \mathrm{Id}$. 
convenience for those unable to vote in person."93 However, this apparently did not affect the court's analysis under Mathews, since the issue was not access to absentee ballots (which was limited under Arizona law) but the counting of those ballots, which the court reasoned was an equally fundamental right whether the ballot had been cast in person or absentee. ${ }^{94}$

The court found the Arizona procedures for determining the validity of absentee ballots to be constitutionally deficient. The central issue was the lack of any notice-either pre-deprivation or post-deprivation-to voters whose ballots had not been counted. ${ }^{95}$ Under Arizona law at the time, members of Absentee Ballots Boards voted on the validity of a ballot in response to a challenge by a member of the Board. ${ }^{96}$ The deficiencies were fairly severe: the decision whether or not to count the ballot (or to disallow it, and therefore deprive the voter of their protected right) was made entirely behind closed doors, with no notice provided to the voter that such a proceeding was taking place or of the result of that proceeding. The court noted that because there was no notice provided to the voter that their ballot had not been counted, the procedure had the possibility of producing errors year after year, since voters might believe their ballots were being counted and never raise the issue with election officials. ${ }^{97}$ The court mentioned the state's interest in preventing fraud almost in passing, apparently dismissing it because that interest had no bearing on any reason the state might have for providing absolutely no notice..$^{98}$

These cases offer persuasive precedent that Mathews applies to challenges to procedures that result in disenfranchisement and provides insight for future litigants in how to bring such claims successfully. ${ }^{99}$ The next subsection will

93 Id. At the time of the Raetzel case, Arizona law only allowed absentee ballot voting if voters met certain conditions. For example, if a voter was unable to report to the polling station on election day. Following the Raetzel decision, the State of Arizona amended the law to provide "no fault" absentee voting. See Act of April 30, 1991, ch. 51, 1991 Ariz. Sess. Laws 136-37. It is unclear based on the court's treatment of the nature of this "privilege" how the court's analysis would have changed in the context of a no-fault absentee voting regime.

${ }^{94}$ Raetzel, 762 F. Supp. at 1358 ("While the state is able to regulate absentee voting, it cannot disqualify ballots, and thus disenfranchise voters, without affording the individual appropriate due process protection.").

$95 \mathrm{Id}$.

${ }^{96} \mathrm{Id}$. at 1357.

${ }^{97} \mathrm{Id}$. at 1358 . The court, therefore, denied the plaintiffs' prayer for relief that voters be given notice at the time a challenge to their ballot is first registered, presumably giving them an opportunity to correct any errors or make a case for their eligibility. The Raetzel ruling, ordering only post-deprivation notice, with no meaningful opportunity to be heard, appears similar to the notice required under HAVA. See 52 U.S.C. § 21082 (Supp. II 2014); infra Part III.A.

98 The court did not engage with the second Mathews factor, the risk of erroneous deprivation. This is likely because the court did not find it necessary, since the risk of error is invariably greater when there is no notice or opportunity to be heard, especially when there is no process whatsoever available to the voter.

${ }^{99}$ See infra Part III. 
analyze cases in which claims of disenfranchisement stemming from a lack of Procedural Due Process have failed in court.

\section{Rejecting Procedural Claims}

In more recent cases, challenges to election administration procedures have failed to take hold in federal court. This subsection will provide a detailed analysis of some of this litigation and attempts to pinpoint why these claims fell short of success in federal court.

The 2008 Sixth Circuit decision in League of Women Voters of Ohio v. Brunner ${ }^{100}$ was the culmination of years of litigation stemming from what may be fairly described as chaos on Election Day in Ohio in 2004. ${ }^{101}$ The plaintiffs brought an array of claims, including violation of both Substantive and Procedural Due Process stemming from mismanagement, dysfunction, and maladministration of Ohio's electoral process. ${ }^{102}$

The plaintiffs' Procedural Due Process claims were largely based on Griffin and Rowe, and pointed to the "virtual gauntlet that Ohio voters must run just to vote." 103 As the Sixth Circuit panel that decided the case later noted, the plaintiffs' Procedural and Substantive Due Process claims were almost entirely intertwined, ${ }^{104}$ but some strictly procedural claims may still be extracted from the plaintiffs' appellate brief. They claimed that voter registrations were "wiped out without notice."105 They also cited problems with voters being directed to incorrect polling places or the incorrect precinct location within a polling place. ${ }^{106}$ The most direct attack on the elections procedures alleged a lack of "sufficient and meaningful notice" pertaining to a host of administrative procedures concerning voting, including registration and the counting of ballots. ${ }^{107}$ They further showed that there was no meaningful opportunity to be heard in those procedures. ${ }^{108}$

${ }^{100}$ League of Women Voters of Ohio v. Brunner, 548 F.3d 463 (6th Cir. 2008).

101 For an account of difficulties faced by voters and the mismanagement of the 2004 election in Ohio based on Congressional hearings convened on the subject, see generally John Conyers, What Went Wrong in Ohio: The Conyers Report on the 2004 Presidential Election in OHIO (Anita Miller ed., 2005).

102 League of Women Voters, 548 F.3d at 477-78.

103 See Final Brief of Plaintiffs-Appellees at 40, League of Women Voters, 548 F.3d 463 (Nos. 06-3335, 06-3483, 06-3621), 2006 WL 6069715.

104 See League of Women Voters, 548 F.3d at 479.

105 Final Brief of Plaintiffs-Appellees, supra note 103, at 40.

${ }^{106}$ Id. at 40-41 ("[T]here is no reliable way to figure out [if voters] are in the 'correct' polling place - or the correct line in the correct polling place- so that the ballot handed to [the voter] by an election official will actually count.").

107 Id. at 41.

108 Id. at 41-42 ("Ohio 'fails to provide adequate or timely process for Ohio citizens to challenge such actions or decisions."'). 
The Sixth Circuit held that the state had committed a violation of Substantive Due Process, but not Procedural Due Process. 109 The court noted that the plaintiffs had not stated a distinct procedural claim, as opposed to a substantive claim, in their appellate brief and that they had not asserted a constitutionally protected interest. ${ }^{110}$ However, the court largely based its decision that the plaintiffs had stated a claim for violation of Substantive Due Process claims on Griffin, viewing this as the sort of "exceptional case" envisioned by Griffin where election administration procedures rises to the level of fundamental unfairness. ${ }^{111}$ This element of the League of Women Voters decision provokes additional confusion, because the court found the plaintiffs had "not alleged a constitutionally protected interest." 112 However, the court apparently had naturally accepted the fact, in its discussion of the plaintiffs Substantive Due Process claims, that the case involved the fundamental right to vote. ${ }^{113}$

The problem with the Procedural Due Process claim as presented to the Sixth Circuit may have been that the plaintiffs did not fully brief the issue as a distinct constitutional violation. While the plaintiffs noted the lack of meaningful notice procedures or opportunities for voters to correct problems, their brief did not articulate a fully formed Procedural Due Process claim. ${ }^{114}$ The brief's discussion of its Equal Protection claim discussed the fundamental nature of the right to vote, but any similar discussion is entirely absent from the plaintiffs' Due Process argument. ${ }^{115}$ Not only did the plaintiffs fail to articulate the nature of the interest, they did not present an argument for why the procedures they were challenging violated Procedural Due Process under the Mathews analysis. ${ }^{116}$ Whether or not a more thorough briefing would have pushed the Sixth Circuit to engage the Procedural Due Process claim more robustly, however, can only be a matter of speculation.

Another Sixth Circuit Procedural Due Process decision in the context of election administration may illustrate the limits of such claims. Hunter $v$. Hamilton County Board of Elections involved a dispute over the validity of provisional ballots in Ohio that had been cast in the wrong precinct due to

${ }^{109}$ League of Women Voters, 548 F.3d at 479.

${ }^{110}$ Id. ("The brevity of argument in the League's brief-which subsumes procedural due process into the substantive due process analysis - reflects the lack of authority for this position.").

${ }^{111} \mathrm{Id}$. at 478. This indicates that the court viewed Griffin as a Substantive Due Process, rather than a Procedural Due Process decision. As previously noted, the decision in Griffin did not specify the theory of Due Process on which the decision was based, but the reasoning of Griffin seems to indicate procedural more than substantive concerns. See supra notes 63-65 and accompanying text.

112 League of Women Voters, 548 F.3d at 479.

$113 \mathrm{Id}$.

114 Id.

115 See Final Brief of Plaintiffs-Appellees, supra note 103, at 39-44.

116 Id 
incorrect instructions rendered to provisional voters by election officials. ${ }^{117}$ Under Ohio law, those ballots could not be counted. ${ }^{118}$ However, under Ohio law precinct election officials were also required to direct voters to the correct precinct, which some election officials had failed to do, resulting in over 100 ballots being cast in the incorrect precinct and subsequently not counted. ${ }^{119}$

When the case reached the Sixth Circuit, the plaintiffs claimed the failure of poll workers to direct voters to the correct precinct violated Procedural Due Process. ${ }^{120}$ This brief tackled the Procedural Due Process claim much more directly than the appellate brief in League of Women Voters. The plaintiffs defined the right at stake as a liberty interest, ${ }^{121}$ and, interestingly, they also defined it as a property interest. ${ }^{122}$ Without presenting a detailed analysis, the plaintiffs referred to Mathews as authority for their Procedural Due Process claim. ${ }^{123}$ As the plaintiffs pointed out, the Ohio provisional voting statute does provide for pre-deprivation notice by requiring election officials to direct the voter to the correct precinct and to inform the voter that if they vote in that precinct, their ballot will not be counted. ${ }^{124}$ However, since that process was not followed for the voters and ballots at issue, the plaintiffs argued that election officials must provide a post-deprivation hearing to allow voters to demonstrate that their ballot was cast in the incorrect precinct due to misinformation from poll workers. ${ }^{125}$ Whether Ohio law allowed such ballots to be counted was immaterial, the plaintiffs argued, because the Due Process Clause does not allow for a "lesser remedy" for persons who are deprived of an interest below what is required by the Due Process Clause itself. 126

Despite a more thorough presentation of the claim than in League of Women Voters, the Sixth Circuit panel ruled against the plaintiffs on their Procedural Due Process claim. As in League of Women Voters, the court's

${ }^{117}$ Hunter v. Hamilton Cty. Bd. of Elections, 850 F. Supp. 2d 795, 818 (S.D. Ohio 2012). The dispute arose from a contested judicial race in the 2010 election.

118 Id. at 808; see also OHIO REV. CODE ANN. § 3505.181(C)(1) (West 2007).

${ }^{119}$ Hunter, 850 F. Supp. $2 \mathrm{~d}$ at 819-22; see also OHIO REv. CODE ANN. $\S 3505.181(\mathrm{C})(1)$. Complicating this case was the fact that Ohio election officials were operating under a federal consent decree requiring that voters cast in the incorrect precinct due to poll worker error nevertheless be counted. See Hunter, 850 F. Supp. 2d at 809-10.

${ }^{120}$ Brief of Plaintiff-Appellee at 29-30, Hunter, 635 F.3d 219 (No. 11-3059), 2011 WL 2191590.

${ }^{121}$ Id. The brief cited as authority Miller v. Blackwell, 348 F. Supp. 2 d 916 (S.D. Ohio 2004) (holding that voting is a liberty interest protected by the Fourteenth Amendment).

${ }^{122}$ However, for this proposition the plaintiffs did not cite to any authority that had previously interpreted the right to vote as a property interest under the Due Process Clause. Brief of Plaintiff-Appellee, supra note 120, at 29-30.

${ }^{123} \mathrm{Id}$. at 30.

${ }^{124}$ Id.; see also OHIO REV. CODE ANN. § 3505.181(C).

125 Brief of Plaintiff-Appellee, supra note 120, at 31.

${ }^{126}$ Id. (quoting Harper v. Virginia Dep't of Taxation, 509 U.S. 86, 102 (1993) (requiring a post-deprivation remedy when pre-deprivation procedures an insufficient to safeguard the constitutional guarantee of Due Process)). 
reasoning is frustratingly thin. The court saw no way that any additional procedures could yield better results, since ballots cast in the wrong precinct were per se invalid under Ohio law. ${ }^{127}$ Therefore, it made no difference whether or not voters could show that they only voted in the wrong precinct because they received incorrect information from poll workers; their ballots still could not be counted. ${ }^{128}$

This decision is problematic for a number of reasons, each of which is complicated by the court's shallow discussion of the Procedural Due Process claim. First, the court did not state whether it was evaluating the right at stake as a property interest or as a liberty interest, or if it was a constitutionally protected right at all.129 This may have a profound effect on the analysis of what procedures are constitutionally required. ${ }^{130}$ Second, the court simply chose to ignore the plaintiffs' assertion that the statutory procedures had not been followed, essentially ruling that those procedural requirements ${ }^{131}$ were unenforceable, since courts could order no recourse under Ohio law.

League of Women Voters and Hunter offer some insights on what pitfalls litigators may need to avoid in order for claims of Procedural Due Process violations to find purchase in federal courts. League of Women Voters demonstrates the imperative to deliberately segregate procedural claims from substantive claims under the Due Process Clause. More generally, the decisions in both cases indicate that these claims may not have been seriously considered. Plaintiffs' litigators bringing Procedural Due Process claims should more fully develop these arguments, which may force courts to more seriously engage with these claims. ${ }^{132}$ Litigants should also consider laying out the elements of the Mathews test to further demonstrate the weightiness of these claims. They should also consider seeking to define the nature of the right at stake. Even if more robust arguments from litigators bringing

${ }^{127}$ Hunter v. Hamilton Cty. Bd. of Elections, 850 F. Supp. 2d 795, 846-47 (S.D. Ohio 2012).

$128 \mathrm{Id}$.

129 Hunter's silence on this point should not indicate that right to vote was not, by itself, a right protected by Due Process. But it is possible that the court viewed the right differently, as the right to cast a provisional ballot, or the right to vote in a precinct other than where a person is registered. Again, the court's silence on this issue raises more questions than answers. Id.

${ }^{130}$ But see Meacham v. Fano, 427 U.S. 215, $223-25$ (1976); Edward L. Rubin, Due Process and the Administrative State, 72 CALIF. L. REV. 1044, 1076 (1984) (pointing out that under the Meacham decision, "[t]he state may eliminate any liberty interest, and thus escape any minimum procedures requirement, by statutory negation").

${ }^{131}$ Specifically, election officials must inform voters of their correct precinct and that provisional ballots cast in the wrong precinct would not be counted. OHIO REV. CODE ANN. $\S 3505.181(\mathrm{C})$ (West 2007).

132 In League of Women Voters, the court all but said the underdeveloped nature of the plaintiff's claim led the court to give that claim only a passing consideration. League of Women Voters of Ohio v. Brunner, 548 F.3d 463, 479 (6th Cir. 2008) (noting "the brevity of argument" in the League's brief). 
Procedural Due Process claims fail to sway courts, forcing them to engage with these issues will contribute to the further development of this area of law.

\section{Anatomy of a Procedural Due Process Claim in Voting}

This Part outlines the general elements that may be necessary to make out a claim for unconstitutional deprivation of Procedural Due Process, based on the previous discussions of Mathews $v$. Eldridge and the federal court precedents relating to such claims.

\section{A. Defining and Weighing the Right(s) at Stake}

The Fourteenth Amendment offers protection against state deprivation of "life, liberty, or property," 133 both as a constraint on the state's regulatory power (Substantive Due Process) and by requiring minimum procedures before protected rights are curtailed (Procedural Due Process). ${ }^{134}$ While property interests may only be created by statute, or by contract, ${ }^{135}$ the origins of the "liberty" protected by the Due Process Clause is far less definite. ${ }^{136}$ While at least one litigant has defined the right to vote as a property interest, ${ }^{137}$ in the view of this author and others, ${ }^{138}$ the concept of liberty is the most consistent with traditional notions of democratic participation and voting. This Section will analyze the right to vote as a potential liberty interest under the Fourteenth Amendment.

While the Supreme Court has analyzed liberty interests most often in cases of physical confinement in the context of arrest or imprisonment, it has also repeatedly held that the liberties protected by the Fourteenth Amendment are not limited to physical restraint. 139 The Court has defined liberty in perhaps its most expansive conception as "privileges long recognized at common law as

133 U.S. CONST. amend. XIV, § 1.

134 SULLIVAN \& MASSARO, supra note 48, at 44.

$135 \mathrm{Id}$. at 62 .

${ }^{136}$ See Bd. of Regents of State Colls. v. Roth, 408 U.S. 564, 571 (1972) (stating that the terms "liberty" and "property" were "purposely left to gather meaning through experience" (quoting Nat'l Mut. Ins. Co. v. Tidewater Transfer Co., 337 U.S. 582, 646 (1949) (Frankfurter, J., dissenting))).

${ }^{137}$ Brief of Plaintiff-Appellee, supra note 120, at 29-30; see supra text accompanying notes $122-28$.

138 See Posner, supra note 40, at 131-32; Pamela S. Karlan, Unduly Partial: The Supreme Court and the Fourteenth Amendment in Bush v. Gore, 29 FLA. ST. U. L. REV. 587, 595 (2001); Shane, supra note 40, at 562-63. But see Epstein, supra note 40, at 18-19 (arguing that the right to vote is not encompassed by either of the terms "liberty" or "property" within the meaning of the Fourteenth Amendment).

139 See, e.g., Roth, 408 U.S. at 572 ("[D]ue process protection for deprivations of liberty [extend] beyond the sort of formal constraints imposed by the criminal process."); Bolling v. Sharpe, 347 U.S. 497, 499 (1954) (“"[L]iberty' . . is not confined to mere freedom from bodily restraint."). 
essential to the orderly pursuit of happiness by free men."140 While the Supreme Court has never explicitly construed the right to vote as one of the liberties protected by the Fourteenth Amendment, the Court has often waxed romantically on the profound importance of the right to vote in general, and particularly in the context of the Equal Protection Clause. ${ }^{141}$

A useful source for defining and precisely locating the origin of voting rights, beyond the florid language of the Supreme Court, are voting provisions in state constitutions. Since voting qualifications are primarily a matter of state law, ${ }^{142}$ and the U.S. Constitution does not grant a positive right to vote, state constitutions are almost universally the documents that confer the right to vote, ${ }^{143}$ subject only to the restrictions of the various U.S. constitutional amendments that have constrained state power to define voting qualifications based on race, ${ }^{144}$ sex, ${ }^{145}$ payment of taxes, ${ }^{146}$ and age. ${ }^{147}$ Therefore, state constitutions must be the ultimate source of the right to vote. ${ }^{148}$

Most state constitutions grant the right to vote based on basic qualifications, such as age and citizenship. ${ }^{149}$ As Professor Douglas has pointed out, many state constitutions that grant an explicit right to vote also grant the right to elections that are "free," "free and equal," or "free and open." 150 While these provisions are subject to the interpretation of state

${ }^{140}$ Meyer v. Nebraska, 262 U.S. 390, 399 (1923). However, while this is an expansive suite of rights, the right to vote is definitively not included in the "privileges long recognized at common law" and the time of Meyer, the right to vote was denied to many Americans. Id.; see Epstein, supra note 40, at 18-19.

${ }^{141}$ Among the most cited are: Reynolds v. Sims, 377 U.S. 533, 561-62 (1964) (defining the right to vote as "a sensitive and important area of human rights," one of the "basic civil rights of man", and "a fundamental matter in a free and democratic society" (quoting Skinner v. Oklahoma, 316 U.S. 535, 536, 541 (1942))); Wesberry v. Sanders, 376 U.S. 1, 17 (1964) ("No right is more precious in a free country than that of having a voice in the election of those who make the laws under which, as good citizens, we must live."); Yick Wo v. Hopkins, 118 U.S. 356, 370 (1886) (voting "is regarded as a fundamental political right, because preservative of all rights").

142 See U.S. ConsT. art. $1, \S \S 2,4$.

143 The singular exception being Arizona. See Joshua A. Douglas, The Right to Vote Under State Constitutions, 67 VAND. L. REV. 89, 102 (2014).

${ }^{144}$ U.S. CONST. amend. XV.

145 U.S. CONST. amend. XIX.

146 U.S. CONST. amend. XXIV.

147 U.S. CONST. amend. XXVI.

148 See Ky. Dep't of Corr. V. Thompson, 490 U.S. 454, 460 (1989) (noting that plaintiffs seeking procedural protections of liberty interest must have "a legitimate claim of entitlement to [the liberty interest]" based on either state law or the Due Process Clause itself).

For a detailed discussion of the operation of state constitutions and the right to vote, see Douglas, supra note 143, at 101-05.

149 Douglas, supra note 143, at 101.

${ }^{150} I d$. at 103-05 (stating that twenty-six state constitutions provide these additional guarantees). 
supreme courts, they may still provide additional rights that may not be restricted with constitutionally sufficient procedures.

Voting rights litigants may also need to define the right at stake with more provisions than simply "the right to vote." Voting is a multi-step process, from registration, to verifying eligibility and identity at the polls, to having a ballot verified (in the case of provisional or absentee ballots), and finally to having a ballot counted. The right to vote is at stake in each step of this process, as at any step the voter may be effectively disenfranchised. While the Supreme Court has said that the right to vote encompasses the right to have that vote counted, ${ }^{151}$ the rights that voters have at these more discrete junctures in the voting process must be defined. For example, several courts have held that the Help America Vote Act (HAVA) creates a protected right to a provisional ballot. ${ }^{152}$ Also, in some states, absentee ballots are available to any voter, while in others voters must meet certain qualifications to vote by absentee ballot. ${ }^{153}$

When courts determine that a constitutionally protected liberty interest is at stake, the next step is to determine the strength of that interest. ${ }^{154}$ Again, the Supreme Court has offered powerful dicta to support the proposition that the right to vote is paramount in a democratic society. ${ }^{155}$ It could be argued that in some instances, certain voters have an even weightier interest in the ability to vote and the validity of their ballot. For example, a convicted felon who has regained her eligibility to vote has an interest in voting that transcends the political right of most voters, since the ability to cast a ballot may reflect that a debt to society has been paid and the voter has now regained the full measure of her citizenship. ${ }^{156}$

151 Wesberry v. Sanders, 376 U.S. 1, 17 (1964).

152 Sandusky Cty. Democratic Party v. Blackwell, 387 F.3d 565, 572-73 (6th Cir. 2004); Fla. Democratic Party v. Hood, 342 F. Supp. 2d 1073, 1077-78 (N.D. Fla. 2004).

${ }^{153}$ For example, voters in Michigan who wish to vote by absentee ballots must meet one of several qualifications. Therefore only voters who meet those qualifications have a right that is, arguably, protected by the Due Process Clause. Mich. CoMP. LAws ANN. $\S 168.758$ (West 2015). Twenty-three other states limit absentee voting to certain categories of voters. See Absentee and Early Voting, NAT'L CONF. ST. LEgISLATURES (Feb. 11, 2015), http://www.ncsl.org/research/elections-and-campaigns/absentee-and-earlyvoting.aspx [https://perma.cc/R2R8-36US].

154 See Morrissey v. Brewer, 408 U.S. 471, 481 (1972).

155 See supra note 138 and accompanying text.

${ }^{156}$ See infra Part III.C. The same might also be said for a voter who is a naturalized citizen, or a voter who is seeking to vote for the first time. These arguments might have little legal force, but sympathetic plaintiffs might help bring a state to a settlement. See infra Part IV.

It also may be argued that a voter has a somewhat weaker interest, relative to the right to vote as a whole, to cast their vote by a regular ballot, as opposed to a provisional ballot. Provisional ballots are just that: provisional. And although these ballots should be counted so long as the voter is eligible and in the correct precinct, they often are not counted. See Field et al., supra note 4 (asserting that nearly one in three provisional ballots are not counted). 


\section{B. Government Interests}

Having measured the importance of the personal interest at stake in a Procedural Due Process claim, the next step is to determine the weightiness of the government's interest in maintaining the current procedural safeguards or not expanding current procedures. ${ }^{157}$

The interests of the state or local election officials will likely be similarly articulated regardless of the specific claims brought by plaintiffs: reducing costs and administrative burdens. Supreme Court decisions relating to ballot access and election administration, though not applying the Mathews analysis, have often noted these interests. ${ }^{158}$ In most states, election administration is decentralized, carried out by local election officials who operate under state law but may not be entirely funded out of state coffers. ${ }^{159}$ Most election officials are volunteers, working for little or no pay, sometimes with minimal training. Requiring these officials to provide additional procedures will inevitably require larger staffs and additional public funding. ${ }^{160}$ With regard to certain junctures of the voting process (such as removing ineligible voters from the rolls, voter identification procedures, and provision ballot verification), states will also claim an interest in preventing fraud. Additional procedures may also increase the amount of time it takes to process each voter at the polls, increasing the already problematic wait times at many polling locations. ${ }^{161}$ In short, the state's asserted interest will likely be orderly, accurate, and efficient election administration on a government budget.

There is, however, an alternative conception of the state interest that voting rights litigators should seek to develop. A fair and accurate election process is undoubtedly one of the cornerstones of any government that seeks to claim legitimacy in the eyes of its citizens. Every state therefore has an interest - in fact, a profound interest - in not only producing an accurate count of votes, but also in ensuring that everyone who seeks to register and vote is

Furthermore, voters could argue that being forced to vote by provisional ballot - in a polling place among their neighbors - may create a stigma, and thus the voter may have a reduced interest in voting by a regular ballot. See infra Part IV.A.1.

${ }^{157}$ Mathews v. Eldridge, 424 U.S. 319, 335 (1976).

158 See, e.g., Burdick v. Takushi, 504 U.S. 428, 441 (1992) ("[T] he right to vote is the right to participate in an electoral process that is necessarily structured to maintain the integrity of the democratic system."); Storer v. Brown, 415 U.S. 724, 730 (1974) ("[T]here must be a substantial regulation of elections if they are to be fair and honest and if some sort of order, rather than chaos, is to accompany the democratic processes.").

159 Richard L. Hasen, The Voting Wars: From Florida 2000 to the Next Election Meltdown 119 (2012); Presidential Commission, supra note 11, at 9-10.

160 Presidential Commission, supra note 11 , at 45.

161 See Elora Mukherjee, Abolishing the Time Tax on Voting, 85 Notre Dame L. ReV. 177, 193-200 (2009) (highlighting the problem of long lines at polling places and citing several studies of wait times nationwide). 
able to do so. ${ }^{162}$ The very legitimacy of the state is, in large part, predicated upon the legitimacy of the process used to select its leaders. ${ }^{163}$

All of these are indeed weighty considerations. Therefore, it would be wise for plaintiffs bringing Procedural Due Process claims pertaining to elections to present the additional procedures that they are seeking in the narrowest terms possible. Plaintiffs may also consider conceding that, yes, Election Day is hard work for election officials - ever has it been thus, and ever shall it be - but that is simply part of the job description of an election official.

\section{The Risk of Erroneous Deprivation and the Benefits of Additional Procedures}

The final element of the Mathews balancing test is a consideration of the risk that the current procedures will erroneously deprive individuals of protected rights and the value of additional procedural guarantees. ${ }^{164}$

This will likely be the biggest obstacle for plaintiffs pursuing Procedural Due Process claims, as it will require a demonstration of mistakes that have occurred under the processes currently in place. Plaintiffs may need to point to actual voters who were erroneously deprived of the right to vote because of a lack of adequate notice or an opportunity to be heard at a meaningful time. ${ }^{165}$ This may mean that such cases may not be brought until after an election has taken place. ${ }^{166}$ Plaintiffs may also seek to demonstrate that procedural deficiencies or abnormalities in election administration rise to the level of fundamental unfairness, which was the standard used to define Due Process violations in election administration in Griffin. ${ }^{167}$ These deficiencies will

162 This conception of the state interest in static procedures is not likely to be what motivates the decisions made by election officials while conducting an election, but it is, arguably, the fundamental interest that underlies all of the work that election officials perform. See Goldberg v. Kelly, 397 U.S. 254, 264-65 (1970).

163 See generally James A. Gardner, Consent, Legitimacy and Elections: Implementing Popular Sovereignty Under the Lockean Constitution, 52 U. PITT. L. REV. 189, 227 (1990) (discussing the relationship between government legitimacy and election administration); Saul Zipkin, Administering Election Law, 95 MARQ. L. REV. 641, 647, 649-52 (20112012).

${ }^{164}$ Mathews v. Eldridge, 424 U.S. 319, 335 (1976) ("[T]he risk of an erroneous deprivation of such interest through the procedures used, and the probable value, if any, of any additional or substitute procedural safeguards ....").

165 City of Los Angeles v. Lyons, 461 U.S. 95, 106 (1983).

166 While this posture may appear on its face to raise mootness concerns because after an election has been certified discarded ballots cannot be added to the vote tally, the Supreme Court has ruled that election administration cases which are decided after an election satisfy an exception to mootness doctrine because they are "capable of repetition, yet evading review." Norman v. Reed, 502 U.S. 279, 287-88 (1992) (quoting Moore v. Ogilvie, 394 U.S. 814, 816 (1969)).

167 See supra Part II.C.1. 
likely need to be systemic or widespread to meet this standard. ${ }^{168}$

Plaintiffs should also state the specific procedural safeguards that they seek to implement and demonstrate how those additional procedures-more adequate notice, pre-deprivation hearing, etc.-will increase the accuracy of the process as a whole. The best way to demonstrate this may be to collect evidence of specific voters who can attest to the fact that they might have taken steps to correct any deficiencies in their registration or their provisional ballot, if they had been made aware of them or if they had been provided with a forum to advocate on their own behalf.

\section{Extent of Notice}

Constitutionally sufficient notice must, as a general matter, inform the individual of the threatened deprivation and give her an adequate opportunity to defend her claim to the right that is at stake. ${ }^{169}$ As in other elements of the Procedural Due Process analysis, the sufficiency of the form and extent of notice is evaluated based on the particular factual and administrative circumstances. ${ }^{170}$

In the context of election administration, a central issue that voting rights advocates will have to grapple with in bringing Procedural Due Process claims is what form of notice is practical in the context of an election. As previously discussed, Election Day and its immediate aftermath are hectic times for election officials. ${ }^{171}$ State and local election officials may argue that it would be difficult or impossible under these circumstances to, for example, contact voters by mail or phone to notify them that their absentee or provisional ballot is somehow deficient and will not be counted. ${ }^{172}$

This argument should fail for several reasons. First, election officials will have easy access to both the mailing address and often the phone number of voters who may be facing a deprivation of their right to vote; the voter's address, at a minimum, is a component of the voter's registration. ${ }^{173}$ Election officials will be examining this very information in the context of determining the validity of an absentee or provisional ballot and thus will have that information directly at hand. ${ }^{174}$ Second, while Election Day is a busy time for

168 See Griffin v. Burns, 570 F.2d 1065, 1076-78 (1st Cir. 1978).

${ }^{169}$ Mullane v. Cent. Hanover Bank \& Tr. Co., 339 U.S. 306, 314 (1950); WASSERMAN, supra note 52, at 84 .

170 Mullane, 339 U.S. at 314.

171 See supra Part III.B.

172 See infra Part IV.A.

173 See, e.g., Mich. Comp. Laws AnN. $§ 168.495$ (West 2008); OHIO. Rev. CodE AnN. $\S 3503$ (West 2007).

174 See Mullane, 339 U.S. at 318 (when the addresses of the persons who are to be deprived of a right are readily available, actual notice is the only constitutionally sufficient form of notice); see also ALA. CODE $\S 17-10-2$ (LexisNexis 2007); 25 PA. STAT. AND CONS. STAT. ANN. § 3146.8 (West Supp. 2015). 
election officials, in most states election officials have at least a week before official returns must be submitted, giving them plenty of time to provide voters with adequate notice, either by mail or by phone, that they may have been deprived of their right to have their ballot counted. ${ }^{175}$

\section{E. Timing of Opportunity to Be Heard}

The general rule of Procedural Due Process is that individuals must receive some form of hearing before they are deprived of a constitutional right. ${ }^{176}$ However, since Mathews is a flexible test, ${ }^{177}$ the circumstances may dictate that a hearing be afforded at another time. Factors that influence when the Constitution requires a hearing include the length or finality of the deprivation 178 and the possibility that an individual may be made whole through a post-deprivation hearing. 179

In the context of voting rights, litigants must define the point of final deprivation for constitutional purposes, as this is a factor in the Mathews analysis. ${ }^{180}$ This may occur when a ballot is initially discarded, or it may be conceptualized as when the election results are certified, since it is not until this point that a voter's ballot will definitively not be part of the final tally. ${ }^{181}$ However, since challenges to ballots that have previously been determined deficient will likely only be made in the context of a contested election (and since the decision by election officials that a ballot be discarded are, in a real sense, final), it will likely be uncontested that the decision by election officials to not count a ballot represents the conclusive deprivation. ${ }^{182}$

The length of the deprivation may also need definition. When the ballot of an eligible voter is discarded, the deprivation is final and absolute. They have lost the ability to influence that particular election and must live under the consequences of that election, which may stretch well into the future. ${ }^{183}$

This also points to the nature of any post-deprivation remedy in a voting rights procedure: this remedy will be wholly inadequate. Therefore, voting

175 See, e.g., Ala. Code $\S 17-10-2$ (c)(1)(b); Pa. Stat. and Cons. STAt. AnN. $\S 3146.8(\mathrm{e})$.

${ }^{176}$ United States v. James Daniel Good Real Prop., 510 U.S. 43, 48 (1993); Cleveland Bd. of Educ. v. Loudermill, 470 U.S. 532, 542 (1985).

${ }^{177}$ Morrissey v. Brewer, 408 U.S. 471, 481 (1972).

178 Gilbert v. Homar, 520 U.S. 924, 932 (1997); Logan v. Zimmerman Brush Co., 455 U.S. 422, 434 (1982).

${ }^{179}$ Mathews v. Eldridge, 424 U.S. 319, 331 (1976) ("A claim to a predeprivation hearing as a matter of constitutional right rests on the proposition that full relief cannot be obtained at a postdeprivation hearing.").

$180 \mathrm{Id}$. at 340.

181 Reynolds v. Sims, 377 U.S. 533, 554-55 (1964) (holding that protections for the right to vote also apply to the right to have the vote counted (citing United States v. Mosley, 238 U.S. 383, 386 (1915))).

182 Mathews, 424 U.S. at 331.

183 See Wesberry v. Sanders, 376 U.S. 1, 17 (1964). 
rights litigators bring Procedural Due Process claims can, and must, argue that they only meaningful hearing that voters can receive is one that occurs prior to the deprivation of their right to vote.

\section{Ghosts in the Machine: Searching For Procedural Due Process Violations in the Electoral Process}

This Part will survey the landscape of controversial aspects of election administration and suggest the ways in which claims of Procedural Due Process may be brought to provide additional procedural safeguards for voters.

\section{A. Provisional and Absentee Ballots}

Under the Help America Vote Act (HAVA), every state ${ }^{184}$ is required to allow voters to cast a provisional ballot if their qualifications for voting are in doubt or if the voter's name does not appear on the registration books. ${ }^{185}$ These ballots will be counted if, upon the investigation of election officials or further information provided by the voter, the voter is found qualified to cast a ballot. ${ }^{186}$ Every state also allows voters to cast an absentee ballot, although some limit this option to certain categories of voters. ${ }^{187}$

In practice, many provisional ballots are not counted and the provisional voting regime has come under serious criticism by liberals and voting reform advocates. ${ }^{188}$ Many states also may reject absentee ballots based on the fact that certain information is missing from the ballot. ${ }^{189}$ Procedural Due Process claims may provide a vehicle for voter advocates to win new procedural protections of provisional and absentee voters.

\section{Provisional and Absentee Ballots}

HAVA itself mandates certain minimal procedures for the issuance of a provisional ballot, which are augmented by state election statutes which provide more detailed procedures and which can vary widely from state to

${ }^{184}$ States that have election-day voter registration regimes are exempt from this requirement, as well as North Dakota, which does not require voters to register. 52 U.S.C. $\S 21082$ (a) (Supp. II 2014).

185 Id.

${ }^{186}$ Help America Vote Act of 2002, 52 U.S.C § 21082(a)(4) (Supp. II 2014).

187 See Absentee and Early Voting, supra note 153.

188 Field et al., supra note 4 (asserting that nearly one in three provisional ballots are not counted and demonstrating that provisional ballots are disproportionately used by racial and ethnic minorities); Leonard Shambon \& Keith Abouchar, Trapped by Precincts? The Help America Vote Act's Provisional Ballots and the Problem of Precincts, 10 N.Y.U. J. LEGIS. \& PUB. POL'Y 133, 136 (2007).

189 Fla. STAT. ANN. $\$ 101.68$ (West 2015); Ohio Rev. Code AnN. $\$ 3509.07$ (West Supp. 2015); Wis. STAT. ANN. § 6.88(3)(a) (West 2013). 
state. ${ }^{190}$ Under HAVA, every voter must be informed of his or her right to cast a provisional ballot. ${ }^{191}$ The voter must then execute a written affirmation declaring that they are eligible to vote and registered to vote in the jurisdiction in which they are seeking to cast a ballot. ${ }^{192}$ Voters must be given written information at the time they cast their provisional ballot on how to ascertain whether or not their vote was counted and, if their vote was not counted, the reasons why. ${ }^{193}$

As a procedural matter, therefore, HAVA does not require that voters be provided with a pre-deprivation notice of why their vote may not be counted, or the opportunity to be heard, i.e., to present additional evidence of their qualifications to vote in the election and in a particular jurisdiction. ${ }^{194}$ Since HAVA does not provide for either notice or an opportunity to be heard, a state which allowed for no further procedures than those mandated by HAVA, would very likely be found in violation of the Procedural Due Process rights of provisional voters under Mathews. ${ }^{195}$

Most voters who vote provisionally do so for one of two reasons: either they do not have sufficient identification, ${ }^{196}$ or they are attempting to cast a ballot in a precinct in which they are not registered or their registration appears to be in doubt. ${ }^{197}$ This raises two questions under Mathews - what information (notice) must poll workers provide to voters to before they cast a ballot that will not be counted and what sort of notice must they be given of their opportunity to cure the deficiencies of a provisional ballot (opportunity to be heard)? Thirty-one states do not allow provisional ballots that are cast in the incorrect precinct to be counted. ${ }^{198}$ Should poll workers be required to inform voters that they are not registered in that precinct and their vote will not be counted? Should they be required to tell voters which precinct, if any, they are registered in? In the realm of voter identification, when a voter casts a provisional ballot because they do not have sufficient identification, how much

190 See, e.g., KAn. STAT. ANN. § 25-409 (West 2008); TenN. CodE AnN. § 2-7-112 (Supp. 2015). See generally Project Vote, MAXIMIZING the EFFectiveness of Provisional Voting 4-10 (Aug. 2006) [hereinafter Provisional Voting], http://www.issuelab.org/resource/maximizing_the_effectiveness_of_provisional_voting [https://perma.cc/C7W4-B73K] (Issues in Election Administration: Policy Brief No. 6).

19152 U.S.C. $\S 21082$ (a)(1) (Supp. II 2014).

192 Id. $\S 21082(\mathrm{a})(2)$.

${ }^{193} I d . \S 21082(\mathrm{a})(5)$.

194 Id.

195 See id:; Mathews v. Eldridge, 424 U.S. 319, 333 (1976) ("The fundamental requirement of due process is the opportunity to be heard 'at a meaningful time and in a meaningful manner."' (quoting Armstrong v. Manzo, 380 U.S. 545, 552 (1965))); Mullane v. Cent. Hanover Bank \& Tr. Co., 339 U.S. 306, 314 (1950) (stating that some sort of notice is a fundamental requirement of Due Process).

${ }^{196}$ Or the voter's identification, while of the type permitted under state law, is somehow lacking or expired, the voter's name has changed, etc.

197 Provisional Voting, supra note 190, at 4.

198 Id. at 7. 
notice should voters be required to be given on what they can do to provide identification and ensure that their ballot is counted?

In the context of provisional voting, "notice" may mean several things. It may refer to information posted at the polling location informing voters of their rights and obligations. ${ }^{199}$ Notice may also apply to written instructions provided to voters on curing a deficiency with their provisional ballot. ${ }^{200}$ Notice may also refer to written or oral contacts between local election officials and voters, informing the voters that their ballots are in some way deficient and instructing them on how to cure these deficiencies. ${ }^{201}$ In the context of provisional voting, "opportunity to be heard" in a process that comports with the Due Process Clause should be translated into a meaningful opportunity for the voter to correct any deficiencies in their provisional ballot that will prevent it from being counted. ${ }^{202}$

So, for example, under Ohio election law, provisional ballots may not be counted if the envelope in which they are sealed is missing information in any of the required fields, including the voter's signature and date of birth. ${ }^{203}$ It is easy to imagine how a voter might forget to bring identification to the polls, be forced to cast a provisional ballot, ${ }^{204}$ and then forget to fill in one field, in the midst of the excitement that many feel while casting their ballot. ${ }^{205}$ A voter in this situation will not have their ballot counted and will have no means of determining whether or not their vote was counted until after it has been tossed, at which point there is no remedy. ${ }^{206}$

Voting systems that allow for such a scenario do not offer a great deal of procedural safeguards. The voter has arguably been given absolutely no notice

${ }^{199}$ HAVA requires the posting of some information, including, among other items, instructions on how to vote and how to cast a provisional ballot, the voters' right to cast a provisional ballot, and instructions on how to make a report of suspected violations of voting rights, including provisional voting. See 52 U.S.C. § 21082(b) (Supp. II 2014).

${ }^{200}$ For example, if the voter must provide proof of identification in order for their provisional ballot to be counted.

${ }^{201}$ If, for example, state law requires that provisional ballot envelopes require certain information in order for the ballots to be counted. See, e.g., OHIO REV. CODE ANN. $\S 3505.183(B)(1)$ (West 2007); TenN. CoDE ANN. § 2-7-112(e)(5) (Supp. 2015). Under these statutes, provisional ballots will not be counted if the envelope they are contained in is lacking certain information.

202 See Provisional Voting, supra note 190, at 7.

203 OHIO REv. CODE ANN. §3505.183(B)(1)(a). The statute states several times that ballot envelopes missing any information may not be counted. At least thirteen other states have the same or similar statutes. See Provisional Voting, supra note 190, at 7.

${ }^{204}$ Under Ohio law, a voter who does not present identification may vote a valid provisional ballot if they provide the last four digits of their social security number or the their Ohio driver's license number. OHIO REV. CODE ANN. § 3503.181.

205 The author is aware of no state statute that would require a poll worker to notify such a voter that they have omitted necessary information from their ballot envelope. This may be an additional species of "notice" that advocates may argue for as part of Procedural Due Process litigation.

206 OHIO REV. CODE ANN. § 3505.181(B)(5). 
that their ballot will not be counted and has categorically been denied any opportunity to be heard, i.e., any chance to correct the deficiencies in her ballot. In order to determine whether a system such as this meets the requirement of the Due Process Clause, we must apply the three-factor test from Mathews. ${ }^{207}$

Individual interest: Under the Supreme Court's voting rights jurisprudence and, indeed, in any democratic nation's conception of individual rights, the right to vote and have that vote counted is one of the most fundamental rights because that right is "preservative of all rights." 208

Benefit of additional procedure: One key procedural addition might serve to alleviate all of these deficiencies: requiring election officials to contact (either by phone, post, or email) voters whose ballots are deficient and notify them what steps they must take in order to have their ballots counted. Plaintiffs seeking to force this additional procedure may need to demonstrate that a significant number of ballots are rejected on these grounds. This would resolve the complete lack of notice or opportunity to be heard in certain states.

Government interest in keeping current procedures: The government will always have an interest in protecting the public treasury by keeping procedures to a minimum. However, in this scenario, the additional strain on public resources would be minimal if procedures were expanded. A simple form letter or perhaps a phone call is all that would be required. ${ }^{209}$

Applying the Mathews test to this scenario, it is likely that a court would find that these provisional ballot procedures are constitutionally insufficient. Litigation and advocacy might be directed towards the following detailed requirements, which could become part of the statutory procedure for verifying and counting provisional ballots:

Poll workers should be required to provide voters who do not present proper identification with detailed written instruction on how and where they can present proper identification in order to have their ballot counted.

Poll workers should be required to notify voters if they have omitted any information from their provisional ballot. Poll workers could also be required to certify, by their signature, that all elements of the ballot have been completed.

Local election officials should be required to provide voters with written notification of the fact that a provisional ballot is deficient in some way and provide every voter with a meaningful opportunity to correct these errors before their ballot is finally rejected.

These simple, common sense reforms would greatly reduce the number of provisional ballots that go uncounted for relatively benign deficiencies. ${ }^{210}$

207 See supra Part II.B.

208 Yick Wo v. Hopkins, 118 U.S. 356, 370 (1886); see supra Part III.A.

${ }^{209}$ Since election officials already have the name and address of every provisional voter, there would be little additional burden in providing actual notice to these voters. See Mullane v. Cent. Hanover Bank \& Trust Co., 339 U.S. 306, 318 (1950).

210 See Provisional Voting, supra note 190, at 7. 
These procedural reforms might also go a long way toward increasing confidence in provisional voting and election administration in general.

This approach may also be used to challenge unfair absentee ballot procedures. Most states require that certain information accompany absentee ballots in order for those ballots to be counted. Some states require the signature of witness to accompany absentee ballots. ${ }^{211}$ If any of the required information is missing from the absentee ballot envelope, the ballots may not be counted, with voters having no opportunity to correct any deficiencies. ${ }^{212}$

Many of the elements of a Procedural Due Process claim against provisional ballot procedures would also apply to a claim that absentee ballot procedures are unconstitutional. However, in this context, the state will have a reduced interest in maintaining current procedures that do not require that voters be notified of ballot deficiencies and provide no opportunity to correct them. Unlike provisional ballots, which are cast on Election Day, many absentee ballots arrive before election officials before Election Day, giving those officials more opportunity, free of the hectic context of canvassing ballots, to contact voters and give them an opportunity to either correct the deficiencies in the ballot, complete a new absentee ballot, or simply vote in person on Election Day if they are able. ${ }^{213}$

\section{Voter Challenges and the Right to Vote by Regular Ballot}

Many states allow voters or political party representatives to challenge the voter-eligibility of other voters at the polls. ${ }^{214}$ These statutes may result in voters casting provisional ballots, which, under HAVA, will be counted so long as the voter meets all eligibility requirements. ${ }^{215}$ Challenges to voters at the polls have come under increasing scrutiny in recent years, with charges that organizations such as True the Vote are engaged in voter intimidation under the guise of preserving electoral integrity. ${ }^{216}$ Because HAVA provides voters with an unqualified right to cast an absentee ballot, this may not be considered a deprivation of or a burden on a constitutional right, allegations of voter intimidation notwithstanding.

On the other hand, voting provisionally may be seen by some voters as a reduced expression of the right to vote. Voting on Election Day is a public event and being relegated to a provisional ballot in the presence of neighbors

211 See, e.g., Ala. CoDE § 17-11-7 (LexisNexis 2007); N.C. GEN. STAT. § 163231(a)(5) (2013).

212 Ala. CODE § 17-11-10; N.C. GEN. STAT. § 163-234(1).

213 Absentee and Early Voting, supra note 153.

214 See, e.g., Fla. Stat. ANN. § 101.111 (West 2015); N.C. Gen. Stat. § 163-85; OHIO REV. CODE ANN. § 3505.21 (West 2007).

215 See supra Part III.A.1.

216 See, e.g., Brennan Ctr. for Justice, Voter Challenges \& Caging, N.Y.U. SCH. L. (Nov. 9, 2012), https://www.brennancenter.org/analysis/voter-challenges-caging [https:// perma.cc/S8P8-V64A]. 
may be a stigmatizing experience. Voting provisionally, by its very nature, means that one's eligibility to vote is in doubt. Moreover, provisional ballots may be seen, rightly or wrongly, as a less reliable vote than voting by regular ballot, since they are less likely to be counted. ${ }^{217}$ This inherent uncertainty may create anxiety for provisional voters and may diminish the sense of civic satisfaction that voters receive by casting their ballot on Election Day.

Voters do have a constitutionally protected right to vote a regular ballot, as opposed to a provisional ballot. ${ }^{218}$ The ability of election officials to deny voters a regular ballot is constrained by state law, thereby creating a right that is protected by the Due Process Clause. ${ }^{219}$ However, in at least one state, many challenged voters will have to vote provisionally simply because they are challenged. $^{220}$ While it may be a strained argument to say that provisional voting is a lesser species of voting, attacking voter challenging procedures under Due Process will serve to highlight these procedure deficiencies and may ensure more attention to issues of fairness in voter challenges, even if plaintiffs are not successful in litigation. ${ }^{221}$

\section{B. Poll Worker Error and Wrong Precinct Voters}

The work of administering elections in the United States is almost entirely a local function. ${ }^{222}$ Poll workers (who are responsible for checking voters' qualifications and registration, providing them with ballots, and assisting voters while maintaining the integrity of the polling place) are mostly lowpaid, temporary workers, without any expertise in election administration. ${ }^{223}$ It is not surprising, then, that they often make errors resulting in the disenfranchisement of voters. 224

One Procedural Due Process avenue through which litigators may challenge poll worker error is under the failure to train theory articulated in City of Canton v. Harris. ${ }^{225}$ In order to show that a failure to sufficiently train

217 Field et al., supra note 4 .

218 U.S. CONST. amend. XXVI.

${ }^{219}$ See Town of Castle Rock v. Gonzales, 545 U.S. 748, 756 (2005); Bd. of Regents of State Colls. v. Roth, 408 U.S. 564, 576-77 (1972).

${ }^{220}$ See Voter Challenges, Fla. Division ElECTIONS (Aug. 2014), https://soe. dos.state.fl.us/pdf/DE-Guide-0009_Guidelines-for-Voter-Challenges_08-2014.pdf [https:// perma.cc/TXG2-CFBQ].

221 See supra Part IV.

222 Presidential Commission, supra note 11, at 1.

223 Advancement Project, Plight OF the Poll Worker: EfForts to IMProve Training AND SuPPORT FOR POll Workers IN OHIO, PenNSYlvania, MARYLAND, FLORIDA, AND MICHIGAN, https://www.supportthevoter.gov/files/2013/ 08/Advancement_Project-Plight-of-the-Poll-Worker.pdf [https://perma.cc/CJ97-XK4M]; Presidential COMMISSION, supra note 11 , at 45-49.

${ }^{224}$ See Lauren Watts, Reexamining Crawford: Poll Worker Error as a Burden on Voters, 89 WASH. L. REV. 175, 177-78 (2014).

225 City of Canton v. Harris, 489 U.S. 378, 380 (1989). 
poll workers violates Procedural Due Process, the decision not to provide poll workers with adequate training must amount to "deliberate indifference" to the rights of voters that will be implicated by the decision; the decision not to train poll workers must rise to the level of a policy choice, rather than an oversight. $^{226}$

The Griffin decision also supplies reasoning that will support a challenge to poll worker error. Recall that in Griffin, absentee ballots that were entirely valid under Rhode Island law at the time they were cast were later determined to be facially invalid. ${ }^{227}$ The court found that the voters who cast those ballots were simply following the instruction of election officials and that when election officials give voters an allegedly valid ballot that is later not counted, the election process becomes fundamentally unfair. ${ }^{228}$ Griffin may be analogous to poll worker errors that result in voters being given provisional ballots when they are not registered in that voting precinct; under the law of many states, such a ballot is invalid and cannot be counted under any circumstances. ${ }^{229}$ Of course, in order for Griffin to be applicable, poll worker errors would have to be sufficiently widespread that the problem rises above the level of "garden variety election irregularities" and "reaches the point of patent and fundamental unfairness." 230 In Griffin, ten percent of ballots were disqualified and although courts may not require a bright line, it is unlikely that election irregularities may rise to this level. ${ }^{231}$

Decisions relating to poll worker error and lack of training of public officials set a high bar for demonstrating that errors of public officials violate Due Process. However, while these cases may not succeed in court, they may have other benefits that might make them attractive cases for voting rights advocates. $^{232}$ For example, in order to avoid litigation over this issue in the future, more states may adopt electronic poll books, which have the possibility of eliminating these forms of poll worker error. ${ }^{233}$

\section{Felon Disenfranchisement}

Most states restrict the voting rights of citizens convicted of felonies. ${ }^{234}$

${ }^{226}$ Id. at $388-89$.

${ }^{227}$ Griffin v. Burns, 570 F.2d 1065, 1067-70 (1st Cir. 1978).

228 Id. at $1075-76$.

229 Provisional Voting, supra note 190, at 7.

230 Griffin, 570 F.2d at $1076-77$.

231 Id. at 1067.

232 See infra Part V.

233 See Katy Owens Hubler, Electronic Poll Books, NAT'L CONF. ST. LegISLATURES (Dec. 14, 2015), http://www.ncsl.org/research/elections-and-campaigns/electronicpollbooks.aspx [https://perma.cc/QL45-TQBX]; see also PRESIDENTIAL COMMISSION, supra note 11 , at $44-46$.

${ }^{234}$ Maine and Vermont are the only exceptions. Felony Disenfranchisement, SENT'G PROJECT, http://www.sentencingproject.org/template/page.cfm?id=133 [https:// perma.cc/2SPR-JQFH]. 
Thirteen states restore voting rights when felons are released from prison. ${ }^{235}$ Twenty-three states disenfranchise felons throughout their parole or probation. ${ }^{236}$ In twelve other states, felons may remain disenfranchised after they have served their entire sentence. ${ }^{237}$ While many states have in recent years amended and relaxed their policies governing the process of reenfranchising ex-felons, this Section will consider the often Byzantine process by which felons are removed from the voting rolls.

Felon disenfranchisement regimes have come under increasing public, political, and scholarly scrutiny. ${ }^{238}$ While these laws are presumed to be facially constitutional under the Supreme Court's ruling in Richardson $v$. Ramirez, ${ }^{239}$ the procedures for determining whether or not a felon be denied the ballot or whether or not a felon has regained the right to vote should still be subject to Procedural Due Process challenges under Mathews. For voting rights advocates, and for advocates on behalf of those convicted of felonies, Procedural Due Process claims may be the best way to challenge these laws. Although there is probably little chance that the Supreme Court will overturn Richardson $v$. Ramirez, challenges to the procedures surrounding felon disenfranchisement may, through either injunctions or simply the negative attention that litigation will bring, force states and the local elections officials charged with carrying out these laws to adopt more cautious procedures in determining who has lost their right to vote and who has regained it.

One aspect of felon disenfranchisement laws that may be ripe for Procedural Due Process challenges are the procedures (or lack thereof) for former felons to regain their voting rights. ${ }^{240}$ This issue highlights the problem with these laws in general, i.e. the comingling of state court, correction, and probation systems with the state electoral system. ${ }^{241}$ These agencies do not often interact, and a lack of communication between them can result in a situation in which felons who have regained their voting rights under state

$235 \mathrm{Id}$

236 Id.

237 Id.

238 See generally Michelle AlEXANDER, THE New Jim CROW: MASS INCARCERATION IN THE AGE OF COLORBLINDNESS (2010); Allen, supra note 6, at 414 (arguing that even in states that allow felons to regain their right to vote, many individuals are, in effect, banned for life); Ann Cammett, Shadow Citizens: Felony Disenfranchisement and the Criminalization of Debt, 117 PenN ST. L. ReV. 349 (2012); Susan E. Marquardt, Deprivation of a Felon's Right to Vote: Constitutional Concerns, Policy Issues and Suggested Reform for Felony Disenfranchisement Law, 82 U. DET. MERCY L. REV. 279 (2005); Brent Staples, The Racist Origins of Felon Disenfranchisement, N.Y. TIMES: OPINION PAGES (Nov. 18, 2014), http://www.nytimes.com/2014/11/19/opinion/the-racistorigins-of-felon-disenfranchisement.html [https://perma.cc/9EVC-4GDW].

${ }^{239}$ Richardson v. Ramirez, 418 U.S. 24, 56 (1974).

240 See generally Allen, supra note 6.

${ }^{241}$ See generally Felon Voting Rights, NAT'L Conf. St. Legislatures (Apr. 25, 2016), http://www.ncsl.org/research/elections-and-campaigns/felon-voting-rights.aspx [https://perma.cc/Z9LS-3PML]. 
laws may be unable to register. ${ }^{242}$ The obvious, and ideal, method of ameliorating these systems of disenfranchisement and re-enfranchisement are legislative, because it will be difficult to otherwise achieve a harmonious procedural framework involving these disparate state and local agencies. However, litigators may push both state legislatures and state agencies to provide more concrete and regularized procedures.

Felon voting rights advocates and litigators should argue that states must provide felons who have regained their voting rights with documentation that they are now eligible to register and vote in the state. In most states, felons automatically regain their voting rights upon completion of all or some of their sentence (imprisonment, parole, or probation). ${ }^{243}$ However, research indicates that a staggering number of these would-be voters are not aware that they have regained the right to vote. ${ }^{244}$ These former felons may not be supplied with documentation of their restored rights, which would allow them to register to vote with state or local election officials, or these officials may not accept such documentation. ${ }^{245}$

The lack of a coordinated system that allows eligible voters to register to vote implicates the Due Process Clause. If ex-felons cannot obtain documentation of their eligibility or when election officials do not accept such documentation, these eligible voters have been denied their right to vote without an effective hearing. Challenges to these deficient procedures may induce state secretaries of state to institute uniform rules for which documents are acceptable for proving eligibility or induce state criminal justice systems to affirmatively provide such documentation.

\section{CONCLUSION: THE BENEFITS FOR VOTING RightS OF EXPLORING Procedural Due Process Claims}

It remains unclear whether, under the Supreme Court's election administration jurisprudence, the Mathews approach to evaluating Procedural Due Process claims applies in this context. ${ }^{246}$ Nevertheless, plaintiffs have brought such claims, and although they have largely been unsuccessful, there

$242 \mathrm{Id}$.

${ }^{243} \mathrm{Id}$. (noting that other states require former felons to apply before their voting rights are restored, and they therefore do not have any constitutionally protected right to vote prior to completing this application).

244 Estelle H. Rogers, Restoring Voting Rights for Former Felons, Project Vote ISSUES IN ELECTION ADMIN. 6 (Mar. 2014), http://www.projectvote.org/issues/votingpolicy/restoration/ [https://perma.cc/WJ74-VCUZ].

245 See Allen, supra note 6, at 415-24 (citing case studies in New York and Missouri where voters were denied the right to register and vote due to allegedly insufficient documentation that they had completed their sentence).

246 See supra Part II.A. 
are reasons to believe that this area of the law may continue to develop if voting rights litigators devote more attention to these claims. ${ }^{247}$

The demise of preclearance under the Voting Rights Act as a result of the Supreme Court's decision in Shelby County ${ }^{248}$ presents an opportunity for voting rights litigators to pursue alternative constitutional arguments against unfair and generally restrictive voting procedures. Many states which would previously have had to clear any changes in their election laws have introduced new laws that have come under fire from voting rights advocates and liberals. ${ }^{249}$ With the possibility of new restrictions in the future, Procedural Due Process claims offer a new weapon for voting rights litigators to challenge these laws in court.

However, claims of procedural deficiencies under the Due Process Clause do not necessarily have to be successful in court to achieve the goals of voting rights advocates. Unlike Equal Protection, Substantive Due Process, or Voting Rights Act claims, Procedural Due Process claims focus specifically on the procedures that accompany voting and are therefore more subject to minor alterations by state and local officials that may not require statutory changes. For example, procedures for determining the validity of a voter's identification may be changed through a directive by the secretary of state, or even by local election officials. Procedural Due Process claims may, merely through the stigma of being sued, induce state and local officials to amend their procedures.

Procedural Due Process lawsuits may also highlight procedural unfairness in election administration and induce legislative changes to these procedures. This approach has been successful in Ohio, where in 2014 the General Assembly passed Senate Bill 216, which would allow provisional ballots cast in the wrong precinct of a multi-precinct polling location to be counted if the ballot was cast due to poll worker error. ${ }^{250}$

Finally, even if plaintiffs who bring Procedural Due Process claims pertaining to voting rights are not successful in court, these efforts, if vigorously pursued, will serve to further develop a body of law that remains fairly stunted. This holds the possibility of expanding the arsenal of voting rights advocates and putting states on notice that they may violate the Constitutional rights of voters even without depriving them of the fundamental right to vote.

247 See supra Part II.C.

248 Shelby Cty. v. Holder, 133 S. Ct. 2612, 2615 (2013).

249 See Ari Berman, The GOP Is Winning the War on Voting, NATION (Oct. 15, 2014), http://www.thenation.com/article/gop-winning-war-voting/ [https://perma.cc/5AB6-M4ZC]; Estelle Rogers, Voter Suppression Schemes Under the Radar After Shelby County Decision, PROJECT Vote (Nov. 6, 2013), http://www.projectvote.org/blog/votersuppression-schemes-under-the-radar-after-shelby-county-decision/ [https://perma.cc/MQK8FA6P].

${ }^{250}$ S.B. 216,130 th Gen. Assemb. (Ohio 2014). 